\title{
Aplysina red band syndrome: a new threat to Caribbean sponges
}

\author{
J. B. Olson ${ }^{1, *}$, D. J. Gochfeld ${ }^{2}$, M. Slattery ${ }^{2,3}$ \\ ${ }^{1}$ Department of Biological Sciences, Box 870344, University of Alabama, Tuscaloosa, Alabama 35487, USA \\ ${ }^{2}$ National Center for Natural Products Research, PO Box 1848, University of Mississippi, University, Mississippi 38677, USA \\ ${ }^{3}$ Department of Phamacognosy, PO Box 1848, University of Mississippi, University, Mississippi 38677, USA
}

\begin{abstract}
A substantial and increasing number of reports have documented dramatic changes and continuing declines in Caribbean coral reef communities over the past 2 decades. To date, the majority of disease reports have focused on scleractinian corals, whereas sponge diseases have been less frequently documented. In this study, we describe Aplysina red band syndrome (ARBS) affecting Caribbean rope sponges of the genus Aplysina observed on shallow reefs in the Bahamas. Visible signs of disease presence included 1 or more rust-colored leading edges, with or without a trailing area of necrotic tissue, such that the lesion forms a contiguous band around part or all of the sponge branch. Microscopic examination of the leading edge of the disease margin indicated that a cyanobacterium was consistently responsible for the coloration. Although the presence of this distinctive coloration was used to characterize the diseased state, it is not yet known whether this cyanobacterium is directly responsible for disease causation. The prevalence of ARBS declined significantly from July to October 2004 before increasing above July levels in January 2005. Transmission studies in the laboratory demonstrated that contact with the leading edge of an active lesion was sufficient to spread ARBS to a previously healthy sponge, suggesting that the etiologic agent, currently undescribed, is contagious. Studies to elucidate the etiologic agent of ARBS are ongoing. Sponges are an essential component of coral reef communities and emerging sponge diseases clearly have the potential to impact benthic community structure on coral reefs.
\end{abstract}

KEY WORDS: Sponge $\cdot$ Aplysina cauliformis $\cdot$ Disease $\cdot$ Syndrome $\cdot$ Coral reef Resale or republication not permitted without written consent of the publisher

\section{INTRODUCTION}

Over the past $20 \mathrm{yr}$, a substantial and increasing number of reports have documented dramatic changes and continuing declines in Caribbean coral reef communities (e.g. Porter \& Meier 1992, Hughes 1994, Jackson 1997, Ward \& Lafferty 2004). These alterations in coral reef communities have been attributed to both natural and anthropogenic factors (Grigg 1994, Ostrander et al. 2000, Jackson 2001), but most likely are the result of the interplay among various factors. These range from increasing global temperature (Vicente 1989, Harvell et al. 1999, Rosenberg \& BenHaim 2002) and altered $\mathrm{CO}_{2}$ levels (Hoegh-Guldberg 2004) to local anthropogenic modifications that affect the overall quality of marine waters (e.g. coastal development, marine- and land-based pollution, overexploitation and destructive fishing, habitat degradation: Done 1999, Harvell et al. 1999, Green \& Bruckner 2000, Jackson et al. 2001). Emerging diseases of marine invertebrates have received increasing attention recently, as infectious disease in the Caribbean sea urchin Diadema antillarum and in scleractinian corals have been shown to be primary causes of the accelerating destruction of Caribbean coral reef systems (e.g. Lessios 1988, Goreau et al. 1998, Hayes \& Goreau 1998, Richardson 1998, Harvell et al. 1999, Cooney et al. 2002, Pantos et al. 2003, Weil 2004). To date, most disease reports have focused on scleractinian corals, whereas sponge diseases have been less 
frequently documented. Relatively few previous conditions or etiologic agents have been described for sponges, and the majority of these discuss commercial bath sponge mortality that occurred during several regional epidemics (Smith 1941, Galstoff 1942, Lauckner 1980 [review], Ayling 1981, Rutzler 1988, Vacelet et al. 1994, Pronzato 1999, Perez et al. 2000, Webster et al. 2002). In this report, we provide a preliminary description of Aplysina red band syndrome (ARBS) affecting the Caribbean sponge $A$. cauliformis observed on shallow reefs in the Bahamas. ARBS is clearly associated with tissue necrosis and is thus presumably a true disease, however, we have yet to identify the etiologic agent responsible for this condition and are presently considering it a syndrome pending characterization of the causal agent.

\section{MATERIALS AND METHODS}

Study site. ARBS-affected sponges were first observed on a shallow reef near the Caribbean Marine Research Center (CMRC) located on Lee Stocking Island (LSI), Exuma Cays, Bahamas. The reef has a maximum depth of $5 \mathrm{~m}$ and consists primarily of large colonies of Montastraea spp., Porites astreoides, and Siderastrea siderea that provide substrate for other coral, gorgonian, and sponge species. Surveys were performed near 2 permanent, CMRC-maintained moorings on Norman's Reef: North Norman's and Big Point. Underwater field sampling and measurements were SCUBA-assisted.

ARBS surveys. Visual characteristics of the syndrome were determined and surveys conducted to assess the prevalence of ARBS. Transects $(2 \times 20 \mathrm{~m})$ were swum in randomly selected directions from each of the permanent moorings by 2 divers, who recorded the total number of Aplysina cauliformis sponges and the number of affected individuals within each transect. Since this species has a meandering, rope-like growth form, individual sponges were characterized as having separate attachments to the substrate. Thus, all growth originating from a single attachment point was considered to be a single individual. Each diver conducted a minimum of 2 surveys per dive; a total of 46 surveys were conducted on Norman's Reef ( 7 in July 2004, 8 in October 2004, 9 in January 2005, 11 in August and 11 in October 2005). Sponge density and ARBS prevalence were compared over time using 1-way ANOVAs. Surveys were also conducted at other sites in the vicinity of LSI, but ARBS prevalence was negligible at these sites until January 2005. Beginning in January 2005, we compared sponge density and syndrome prevalence at Rainbow Gardens (6 to 9 surveys per sampling period), a nearby site with simi- lar habitat characteristics, with those at Norman's Reef using unpaired $t$-tests.

Collection of specimens for microbiological analysis. Small pieces of affected and adjacent unaffected sponge tissue were removed underwater using scissors and placed into Ziploc bags. Samples were kept at ambient temperature and processed immediately upon return to the laboratory. Samples were stored in $70 \%$ ethanol, RNALater (Ambion), and glycerol-amended sterile seawater for subsequent microscopic examination, molecular genetic analyses, and cultivation, respectively.

Microscopic examination of affected sponges. Small segments of the leading edge of the affected tissue were removed using sterile technique, placed into a microcentrifuge tube with $50 \mu$ of sterile artificial seawater, and gently macerated. A small portion of the resulting slurry was placed onto a microscope slide and examined under phase contrast using 40× and $100 \times$ objectives on a Nikon E600 microscope. Autofluorescence of photopigments was visualized using UV excitation under the same magnification. Digital photographs were taken with a Spot RT 2.2.0 color camera system.

Transmission of ARBS. To determine whether the observed syndrome was contagious, transmission experiments were performed in the laboratory at CMRC. Samples (15 to $25 \mathrm{~cm}$ ) were collected from both healthy and affected Aplysina cauliformis sponges at Norman's Reef in July 2004 and January 2005, and $7 \mathrm{~d}$ challenge experiments were performed (for each treatment, $\mathrm{n}=5$ in July and $\mathrm{n}=5$ in January) using 61 plastic aquaria containing flow-through filtered seawater. Prior to the experiments, a cable tie was placed around a healthy part of each ARBSaffected sponge and the distance from the cable tie to the near and far edge of the lesion was measured. The first treatment tested whether the syndrome was communicable via water flow alone. In this treatment, water from an aquarium containing an affected sponge flowed directly and continuously into an aquarium containing a healthy sponge. The second treatment determined whether physical contact was required for syndrome transmission. In this treatment, a healthy sponge was cable-tied to an ARBS-affected sponge such that the lesion was in direct contact with the healthy sponge tissue. We also performed 2 controls: healthy sponges cable-tied to another healthy sponge (contact control), and healthy sponges alone (handling control). After $7 \mathrm{~d}$ the sponges were reexamined, all lesions were photographed and measured, and the sponges preserved for future molecular and chemical analysis. Results from the same experiments conducted in July and January were compared using chi-squared tests. Since there was no difference 
between dates ( $p>0.05$ for each experiment type), results from both dates were pooled and treatment effects were tested against a null hypothesis of no syndrome transmission using chi-squared tests.

\section{RESULTS AND DISCUSSION}

On shallow-water reefs in the Caribbean, Aplysina spp. sponges are among the dominant species. To date, only A. cauliformis appears to be affected by ARBS at our study sites in the Bahamas; however, recent work has demonstrated that several species of Aplysina are extremely genetically similar (including $A$. fulva and A. cauliformis; Schmitt et al. 2005), suggesting that ARBS may have the potential to affect other species. Visible signs of ARBS included 1 or more rust-colored leading edges, with or without a following area of necrotic tissue (Fig. 1), such that the lesion formed a contiguous band around part or all of the sponge branch. When sponge tissue necrosis was noted without the presence of the rust-colored leading edge, it was not recorded as positive for this syndrome. Microscopic examination of the leading edge of the affected tissue showed that a cyanobacterium was consistently associated with the coloration (Fig. 2). This cyanobacterium was morphologically distinct; however, we could not identify it based solely on morphology. Although the presence of this distinctive coloration was used for characterizing the affected state, it is not yet known whether this cyanobacterium is directly responsible for ARBS. There is a single report of a cyanobacterial disease in sponges (Rutzler 1988), although that disease is distinct from the syndrome reported here in the sponge species affected (Geodia papyracea) and the absence of the colored leading edge. Molecular genetic studies to identify this cyanobacterium and other associated microorganisms are ongoing.

The prevalence of ARBS on Norman's reef ranged from 3.2 to $12.2 \%$ over the study period. ARBS prevalence declined significantly from July to October 2004, but increased by January 2005, before gradually decreasing again by October 2005 (MS $=0.015, F=$ 3.722, p =0.008; Fig. 3). Meanwhile, the density of Aplysina cauliformis on Norman's reef declined by approximately $73 \%$ from July to October 2004 and only recovered slightly by August 2005, followed by a greater increase in October 2005 (MS = 1.159, $F=$ 12.624, p < 0.0001; Fig. 3). By August 2005, sponge density remained $55 \%$ lower than in July 2004, yet the prevalence of ARBS did not differ significantly $(\mathrm{p}=$ 0.80). Although some of the July to October 2004 decrease in sponge density at Norman's reef may have been due to ARBS, it is more likely that this resulted from 2 major hurricanes that swept through the Bahamas in September 2004 ('Frances' and 'Jeanne'), causing many loosely attached sponges to be dislodged from the substrate. No major storms hit LSI in the 2005 hurricane season, allowing continued recovery. While there may be a seasonal periodicity in ARBS infection rates, 2 alternative hypotheses may account for the decrease in ARBS prevalence from July to October 2004 and again from August to October 2005. In October, many sponges were observed to have patches of necrotic tissue, but the distinctively colored leading edge that we associate with ARBS was not always visible. Thus, we were unable to determine whether the tissue loss was caused by a previous, self-limiting ARBS infection, or by some other biotic or abiotic stress (e.g. sediment scour during hurricane storm waves), and we did not include these sponges in our counts of affected individuals. Additionally, affected sponges may have suffered greater hurricane-induced mortality, as subsequent long-term monitoring of affected individuals indicates that breakage tends to occur at the necrotic portion of the lesion. Continued investigations will address temporal patterns of ARBS prevalence. The elevated prevalence of ARBS on the remaining sponges at Norman's reef suggests that these surviving sponges may be more susceptible to ARBS, and chemical ecology and immunological studies to address this issue are ongoing.

Affected individuals of Aplysina cauliformis were also observed at other sites in the vicinity of LSI, initially at much lower densities than at Norman's reef, but with increased prevalence by January 2005. Transects conducted at Rainbow Gardens in January 2005 indicated the presence of ARBS where none had been observed previously. ARBS prevalence at Rainbow Gardens increased to Norman's reef levels by August 2005 ( $p=0.0007$ in January 2005, p > 0.05 in August and October 2005), whereas the density of A. cauliformis remained significantly lower than at Norman's Reef ( $p<0.05$ in January and October 2005, $p=0.06$ in August 2005). It appears that ARBS incidence and prevalence are increasing on reefs in the Bahamas.

Transmission studies demonstrated that contact with the lesion was sufficient to spread ARBS to a previously healthy sponge, suggesting that the etiologic agent (currently undescribed) is contagious. In 7 out of 10 cases, a lesion was evident on the healthy sponge after $7 \mathrm{~d}$ of contact with an affected sponge $(\mathrm{p}=0.001$; Table 1). Our experiments also suggested that the etiologic agent may be transmitted in the water column, although this mechanism was considerably less effective than direct contact, at least over the short time scale examined. Only 1 out of 10 healthy sponges became infected and we cannot rule out the possibility that the 1 infected sponge had already had a very early 

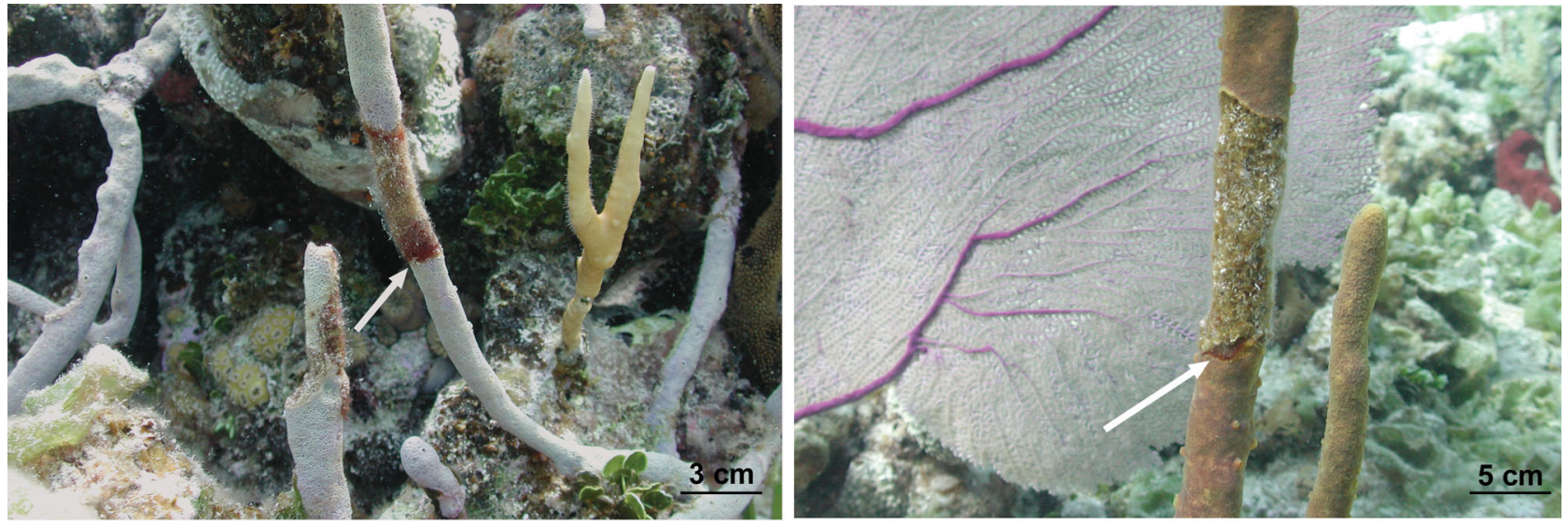

Fig. 1. Aplysina cauliformis with Aplysina red band syndrome. Arrows point to leading edge of affected tissue

ARBS infection prior to the experiment. Neither the healthy sponges alone nor those in contact with other healthy sponges acquired an infection. The size of the lesions on affected sponges did not change during the experiment $(4.19 \pm 1.57 \mathrm{~cm}$ diameter). Based on the short duration of these experiments, it was not possible to discern whether the rust-colored leading edge of this syndrome travels in more than one direction at any point in time.
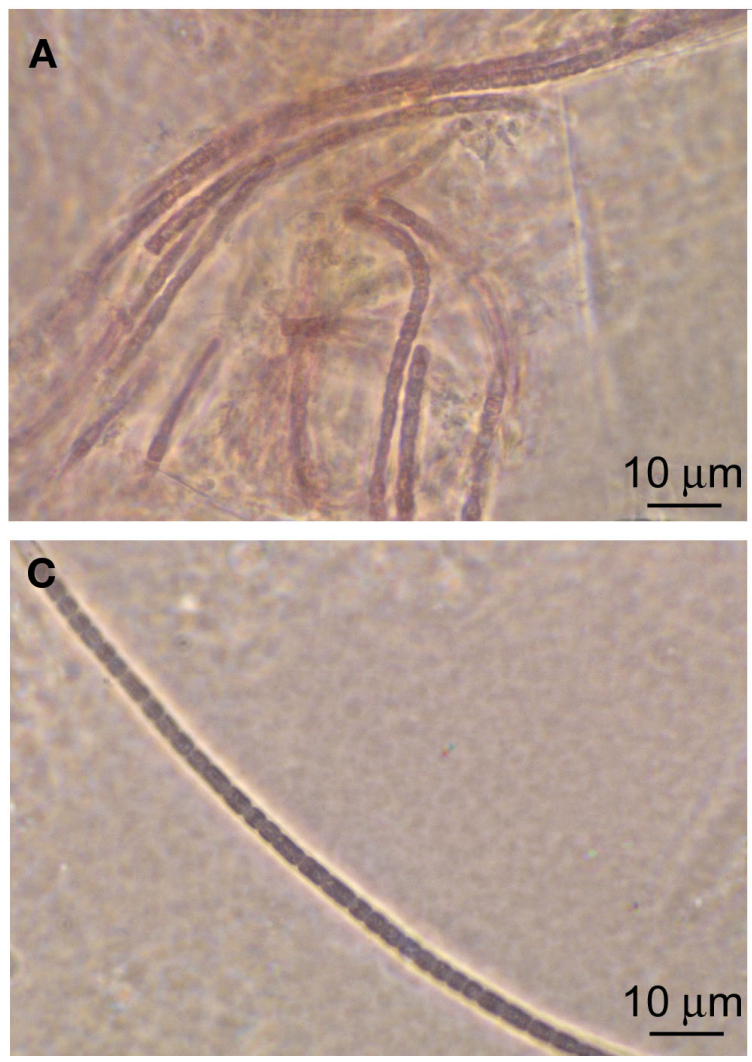

The condition described herein appears unlike those described previously (Galstoff 1942, Ayling 1981, Rutzler 1988, Vacelet et al. 1994, Webster et al. 2002). While the causative agent for ARBS has yet to be determined, Vacelet et al. (1994) suggested and Webster et al. (2002) demonstrated that bacteria (e.g. $\alpha$-proteobacteria strain NW4327) can successfully attack and cause disintegration of sponge fibers or tissue. Many marine sponges, including Aplysina species,
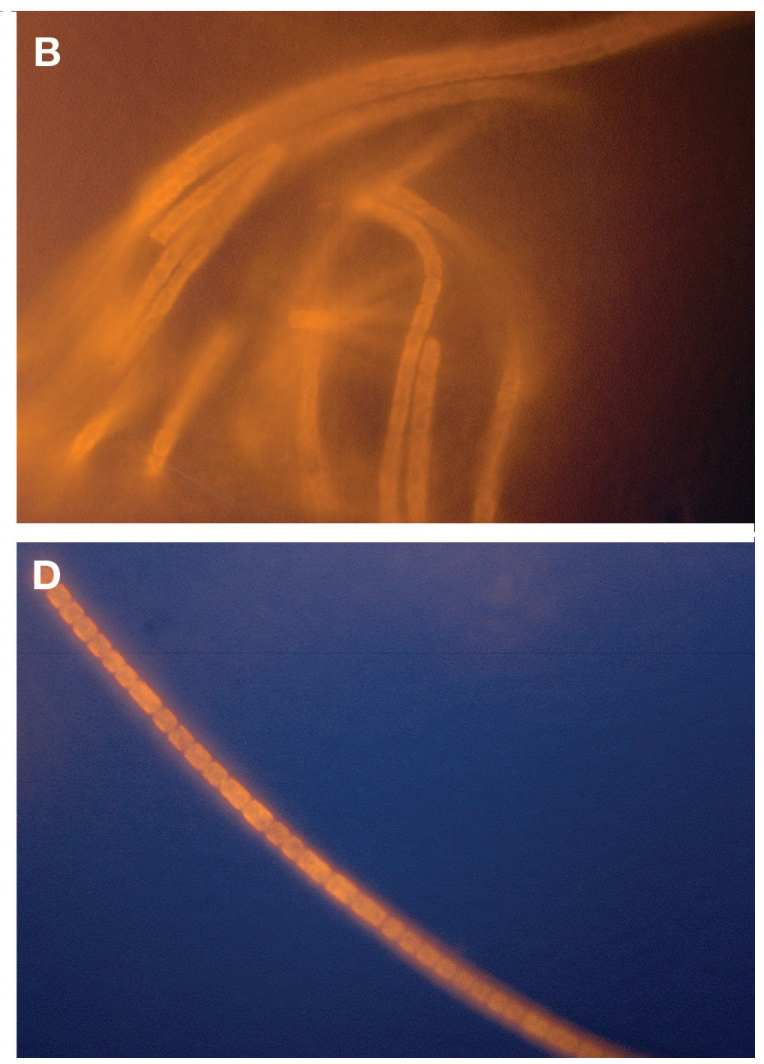

Fig. 2. (A,C) Phase contrast images of cyanobacterium associated with margin of affected tissue of Aplysina cauliformis; $(B, D)$ same images under UV excitation, demonstrating the autofluorescence of photopigments 


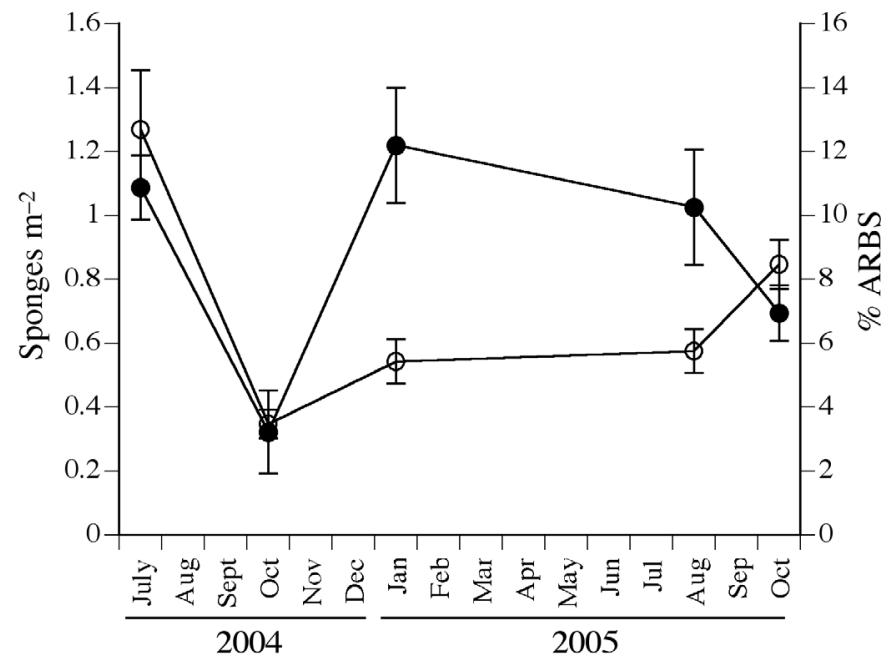

Fig. 3. Aplysina cauliformis. (O) Mean $( \pm \mathrm{SE})$ density of sponges and (-) percent prevalence of ARBS on Norman's Reef in July and October 2004 and January, August, and October 2005

have spongin fibrous support systems rather than calcareous or siliceous skeletons. The cyanobacterium associated with ARBS of Caribbean A. cauliformis may be the etiologic agent, or it may be a secondary opportunistic pathogen taking advantage of a syndrome caused by another microbe or microbial consortium. Because sponges often support diverse microbial communities that may be distinct from those in the surrounding water column (Wilkinson 1978, Santavy \& Colwell 1990, Burja \& Hill 2001, Hentschel et al. 2002, Hentschel 2004, Taylor et al. 2005), the causative agent of this syndrome may be a normal constituent of the commensal community that becomes opportunistically pathogenic when the host's immune system is compromised (Bohm et al. 2001).

In summary, we have described a condition (ARBS) causing tissue necrosis in Aplysina cauliformis sponges from shallow Caribbean reefs. As sponges are an essential component of Caribbean coral reefs (Diaz \& Rutzler 2001, Wulff 2001), understanding the disease processes in these organisms is critical. This study

Table 1. Aplysina cauliformis. Percent of healthy sponges acquiring ARBS infection during transmission experiments ( $\mathrm{n}=10$ for each treatment). ns: not significant

\begin{tabular}{|lcc|}
\hline $\begin{array}{l}\text { Transmission } \\
\text { treatment }\end{array}$ & $\%$ infected & $\begin{array}{c}\text { Chi-squared } \\
\text { p-value }\end{array}$ \\
\hline Contact & 70 & 0.001 \\
Water-borne & 10 & ns \\
Control (contact) & 0 & ns \\
Control (handling) & 0 & ns \\
\hline
\end{tabular}

continues efforts to expand our understanding of etiologic agents of marine coral reef diseases and disease transmission, and to make accurate assessments of coral reef health.

Acknowledgements. Funding for this research was provided by a NOAA-NURP National Institute of Undersea Science and Technology grant to J.B.O. (NA16RU1496). We also acknowledge the facilities and personnel support of the Caribbean Marine Research Center. Thanks to R. Findlay and R. Thacker for editorial suggestions during manuscript preparation and D. Goulet and T. Hodges for field assistance. This is contribution number CMRC-04-ORJL-01-05C of the Caribbean Marine Research Center.

\section{LITERATURE CITED}

Ayling AM (1981) The role of biological disturbance in temperate subtidal encrusting communities. Ecology 62:830-847

Bohm M, Hentschel U, Friedrich AB, Fieseler L, Steffen R, Gamulin V, Muller IM, Muller WEG (2001) Molecular response of the sponge Suberites domuncula to bacterial infection. Mar Biol 139:1037-1045

Burja AM, Hill RT (2001) Microbial symbionts of the Australian Great Barrier Reef sponge, Candidaspongia flabellata. Hydrobiologia 461:41-47

Cooney RP, Pantos O, LeTissier MDA, Barer MR, O'Donnell AG, Bythell JC (2002) Characterization of the bacterial consortium associated with black band disease in coral using molecular microbiological techniques. Environ Microbiol 4:401-413

Diaz MC, Rutzler K (2001) Sponges: an essential component of Caribbean coral reefs. Bull Mar Sci 69:535-546

Done TJ (1999) Coral community adaptability to environmental change at the scales of regions, reefs, and reef zones. Am Zool 39:66-79

Galstoff PS (1942) Wasting disease causing mortality of sponges in the West Indies and Gulf of Mexico. Proc 8th Am Sci Congr 3:411-421

Goreau TJ, Cervino JM, Goreau M, Hayes RL and 13 others (1998) Rapid spread of diseases in Caribbean coral reefs. Rev Biol Trop 46:157-172

Green EP, Bruckner AW (2000) The significance of coral disease epizootiology for coral reef conservation. Biol Conserv 96:347-361

Grigg RW (1994) Effects of sewage discharge, fishing pressure and habitat complexity on coral ecosystems and reef fishes in Hawaii. Mar Ecol Prog Ser 103:25-34

Harvell CD, Kim K, Burkholder JM, Colwell RR and 9 others (1999) Emerging marine diseases - climate links and anthropogenic factors. Science 285:1505-1510

Hayes RL, Goreau TJ (1998) The significance of emerging diseases in the tropical coral reef ecosystem. Rev Biol Trop 46:173-185

Hentschel U (2004) Microbial diversity of marine sponges. Boll Mus Ist Biol Univ Genova 68:365-372

Hentschel U, Hopke J, Horn M, Friedrich AB, Wagner M, Hacker J, Moore BS (2002) Molecular evidence for a uniform microbial community in sponges from different oceans. Appl Environ Microbiol 68:4431-4440

Hoegh-Guldberg O (2004) Coral reefs and projections of future change. In: Rosenberg E, Loya Y (eds) Coral health and disease. Springer-Verlag, Berlin, p 463-479 
Hughes TP (1994) Catastrophes, phase shifts and large scale degradation of a Caribbean coral reef. Science 265:1547-1549

Jackson JBC (1997) Reefs since Columbus. Coral Reefs 16(Suppl):23-32

Jackson JBC (2001) What was natural in the coastal oceans? Proc Natl Acad Sci USA 98:5411-5418

Jackson JBC, Kirby MX, Berger WH, Bjorndal KA and 15 others (2001) Historical overfishing and the recent collapse of coastal ecosystems. Science 293:629-638

Lauckner G (1980) Diseases of Porifera. In: O. Kinne (ed) Diseases of marine animals. Wiley \& Sons, Chichester, p 139-165

Lessios H (1988) Mass mortality of Diadema antillarum in the Caribbean: What have we learned? Annu Rev Ecol Syst 19:371-393

Ostrander GK, Armstrong KM, Knobbe ET, Gerace D, Scully EP (2000) Rapid transition in the structure of a coral reef community: the effects of coral bleaching and physical disturbance. Proc Natl Acad Sci 97:5287-5302

Pantos O, Cooney RP, LeTissier MDA, Barer MR, O'Donnell AG, Bythell JC (2003) The bacterial ecology of a plaguelike disease affecting the Caribbean coral Montastrea annularis. Environ Microbiol 5:370-382

Perez T, Garrabou J, Sartoretto S, Harmelin JG, Francour P, Vacelet J (2000) Mortalité massive d'invertébrés marins: un événement sans précédent en Méditerranée nordoccidentale. Life Sci 323:853-865

Porter JW, Meier OW (1992) Quantification of loss and change in Floridian reef coral populations. Am Zool 32:625-640

Pronzato R (1999) Sponge-fishing, disease and farming in the Mediterranean Sea. Aquat Conserv: Mar Freshw Ecosyst 9:485-493

Richardson LL (1998) Coral diseases: What is really known? Trends Ecol Evol 13:438-443

Rosenberg E, Ben-Haim Y (2002) Microbial diseases of corals and global warming. Environ Microbiol 4:318-326

Rutzler K (1988) Mangrove sponge disease induced by

Editorial responsibility: Albert K. Sparks,

Seattle, Washington, USA cyanobacterial symbionts - failure of a primitive immunesystem. Dis Aquat Org 5:143-149

Santavy D, Colwell RR (1990) Comparison of bacterial communities associated with the Caribbean sclerosponge Ceratoporella nicholsoni and ambient seawater. Mar Ecol Prog Ser 67:73-82

Schmitt S, Hentschel U, Zea S, Dandekar T, Wolf M (2005) ITS-2 and 18S rRNA gene phylogeny of Aplysinidae (Verongida, Demospongiae). J Mol Evol 60:327-336

Smith FG (1941) Sponge disease in British Honduras, and its transmission by water currents. Ecology 22:415-421

Taylor MW, Schupp PJ, de Nys R, Kjelleberg S, Steinberg PD (2005) Biogeography of bacteria associated with the marine sponge Cymbastela concentrica. Environ Microbiol 7:419-433

Vacelet J, Vacelet E, Gaino E, Gallissian MF (1994) Bacterial attack of spongin skeleton during the 1986-1990 Mediterranean sponge disease. In: van Soest RWM, van Kempen ThMG, Braekman JC (eds) Sponges in time and space. AA Balkema, Rotterdam, p 355-362

Vicente VP (1989) Regional commercial sponge extinctions in the West Indies: Are recent climatic changes responsible? PSZN I: Mar Ecol 10:179-191

Ward JR, Lafferty KD (2004) The elusive baseline of marine disease: are diseases in ocean ecosystems increasing? PLOS Biol 2:542-547

Webster NS, Negri AP, Webb RI, Hill RT (2002) A sponginboring $\alpha$-proteobacterium is the etiological agent of disease in the Great Barrier Reef sponge Rhopaloeides odorabile. Mar Ecol Prog Ser 232:305-309

Weil E (2004) Coral reef diseases in the wider Caribbean. In: Rosenberg E, Loya Y (eds) Coral health and disease. Springer-Verlag, Berlin, p 35-68

Wilkinson CR (1978) Microbial associations in sponges. II. Numerical analysis of sponge and water bacterial populations. Mar Biol 49:169-176

Wulff J (2001) Assessing and monitoring coral reef sponges: Why and how? Bull Mar Sci 69:831-846

Submitted: July 13, 2005; Accepted: January 25, 2006

Proofs received from author(s): July 5, 2006 